$$
\text { CONF-9705140-1 }
$$

\title{
THE USE OF CARBONATE LIXIVIANTS TO REMOVE URANIUM FROM URANIUM-CONTAMINATED SOILS
}

\author{
Chester W. Francis \\ Corresponding Author
}

E-Mail Address: chetfrancis@compuserve.com

Michael E. Timpson

Oak Ridge Institute for Science and Education

P. O. Box 117

Oak Ridge, Tennessee 37831-0117

Suk Y. Lee

Environmental Sciences Division*

Oak Ridge National Laboratory

P.O. Box 2008

Oak Ridge, Tennessee 37831-6038

Mark P. Elless

Oak Ridge Institute for Science and Education

P. O. Box 117

Oak Ridge, Tennessee 37831-0117

Jim H. Wilson

Chemical Technology Division*

Oak Ridge National Laboratory

P. O. Box 2008

Oak Ridge, Tennessee 37831

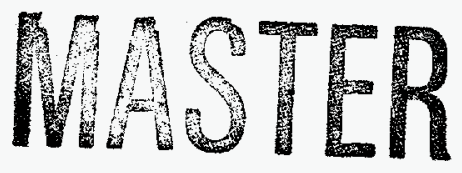

*Managed by Lockheed Martin Energy Research Corp., under contract DE-AC05-96OR22464 with the U.S. Department of Energy. 
The following manuscript was presented at the 7th International Conference Separation of Ionic Solutes (SIS'97), May 18-23, 1997, Piestany Spa, Slovakia. It will published in the special issue of the Journal of Radioanalytical and Nuclear Chemistry. 


\title{
THE USE OF CARBONATE LIXIVIANTS TO REMOVE URANIUM FROM URANIUM-CONTAMINATED SOILS
}

Chester W. Francis, ${ }^{1}$ Michael E. Timpson, ${ }^{2}$ Suk Y. Lee, Mark P. Elless, ${ }^{2}$ Jim H. Wilson ${ }^{3}$

Environmental Sciences Division, Oak Ridge National Laboratory, P.O. Box 2008, Oak Ridge, Tennessee 37831

\begin{abstract}
The objective of this research was to design an extraction media and procedure that would selectively remove uranium without adversely affecting the soils' physicochemical characteristics or generating secondary waste forms difficult to manage or dispose of. Investigations centered around determining the best lixivant and how the various factors such as $\mathrm{pH}$, time, and temperature influenced extraction efficiency. Other factors investigated included the influence of attrition scrubbing, the effect of oxidants and reductants, and the recycling of lixiviants. Experimental data obtained at the bench-and pilot-scale levels indicated 80 to $95 \%$ of the uranium could be removed from the uranium-contaminated soils by using a carbonate lixiviant. The best treatment was three successive extractions with $0.25 \mathrm{M}$ carbonate-bicarbonate (in presence of $\mathrm{KMnO}_{4}$ as an oxidant) at $40 \mathrm{C}$ followed with two water rinses.
\end{abstract}

\section{INTRODUCTION}

Production of enriched uranium requires a variety of chemical and metallurgical processes. As a consequence, uranium in various forms has been released to the environment at a number of U.S. Department of Energy (DOE) facilities. Uranium sources include uranium airborne particulate coming from the stacks of the facilities as well as leaks and spills of uranium-rich solvents and process effluents generated in the wide assortment of aqueous and nonaqueous extraction and treatment processes related to uranium enrichment. One of the major receptors of uranium releases has been soils. The exact quantity of uranium-contaminated soils across the DOE sites is unknown.

One DOE site known to have significant quantities of uraniumcontaminated soils is the facility formerly known as the Feed Materials

\footnotetext{
${ }^{1}$ Corresponding author, e-mail address: chetfrancis@compuserve.com.

${ }^{2}$ Oak Ridge Institute for Science and Education, Oak Ridge, Tennessee.

${ }^{3}$ Chemical Technology Division, Oak Ridge National Laboratory
} 
Production Center at Fernald, Ohio. Activities at the Fernald site centered around production of purified uranium metal, and it is estimated that 1 to 1.5 million $\mathrm{m}^{3}$ of soil containing unacceptable levels of uranium are present in the top surface soil layers'. Uranium concentrations are as high as $70,000 \mathrm{mg} / \mathrm{kg}$ in soils adjacent to the processing plants. It is estimated that $>50 \%$ of the surface soils (to the top $0.5 \mathrm{~m}$ ) contain unacceptable levels of uranium. At certain locations, (e.g., within the waste pit areas) significant contamination is also present at soil depths $>4.5 \mathrm{~m}$. To eliminate the need for collection and disposal of the uranium-contaminated soil in engineered landfills, methods to decontaminate the soil have been investigated.

The objective of this research is to design an extraction media and procedure that would selectively remove the uranium without adversely affecting the soils' physicochemical characteristics or generating secondary waste forms difficult to manage or dispose of. The work reported here summarizes the approach as to selection of extraction media and demonstrates the feasibility of using carbonate lixivants to decontaminate uranium-contaminated soils. Data are presented on how various scientific and engineering parameters (i.e., time, temperature, $\mathrm{pH}$, concentrations and characteristics of lixivants, attrition scrubbing, additions of oxidants, successive and recyled lixivants) affected uranium removal from two soils at the Fernald site.

\section{APPROACH}

\section{Characterization of Soils}

Two soils considered to be representative of the uranium source terms at the Fernald site were used for testing. One included soil adjacent to a. storage pad area because it represented uranium contamination by a soluble uranium source-term (i.e., dissolved uranium contained in run-off from the storage pad). The other soil, soil adjacent to a low-temperature waste incinerator, represented an air-borne source term of uranium at the Fernald site. Characterization studies have indicated that the predominant oxidation state of uranium in both of the soils was the uranyl form.

Uranium in the incinerator soil was typically found to be associated with particles in the 1 to $10 \mu \mathrm{m}$ diameter range as calcium uranyl phosphate (meta-autunite) while uranium in the storage pad soil was seldom observed to be in discrete particles and was thought to be predominantly schoepite (uranyl oxide hydrate) in close association with the amorphous iron oxyhydroxide coatings on soil particles ${ }^{2,3,4}$. The concentrations and distribution of uranium in the Fernald soils with respect to the particle size fractions of soil are presented in Table 1. Uranium concentrations in both 
soils were fairly similar (538 and $446 \mathrm{mg} / \mathrm{kg}$, respectively for the incinerator and storage pad soils). Greater than $70 \%$ of the uranium in the incinerator soil was associated with the silt and sand fractions (particle size fractions $>0.002 \mathrm{~mm}$ ). All of the size fractions contained uranium in concentrations $>52 \mathrm{mg} / \mathrm{kg}$, the targeted cleanup level.

\section{Potential Removal Processes for Uranium}

Soil washing in a conventional sense is based on a physical separation process. Methods of physical separation such as screening, classification (separation of soil particulate according to their settling velocities), and flotation are effective for soils in which a large amount of the contamination is concentrated in the fine-grain fraction (i.e., a small percentage of the soil volume). However, these methods are not effective in the removal of contaminants from heavy-textured soils [those soils containing high concentrations of clays $(<0.002 \mathrm{~mm})$ and silts $(0.053-$ $0.002 \mathrm{~mm}$ )]. Most soil washing operations employ a "cut" at particle size diameters $>0.053 \mathrm{~mm}$. For these Fernald soils a fractionation at $0.053 \mathrm{~mm}$ would remove $73 \%$ and $93 \%$ of the uranium from the incinerator and storage pad soil, respectively; but it would also constitute $94 \%$ and $75 \%$ of the two soils respectively. The remaining sand fractions of the two soils would contain uranium concentrations (1033 and $117 \mathrm{mg} / \mathrm{kg}$ ) well in excess of the targeted $52 \mathrm{mg} / \mathrm{kg}$ cleanup level. Thus, a simple physical separation process would not be an effective cleanup technology and any successful approach would likely depend on a chemical extraction process.

Chemical extraction processes characteristically used to remove uranium from uranium ores are either acid or carbonate based extractions. For acid extractions, sulfuric acid, which is less expensive than nitric, is the most commonly used acid extractant and can remove 90 to $98 \%$ of the uranium. When ores containing uranium in the hexavalent state are leached with sulfuric acid, stable highly soluble complexes of uranyl sulfates are formed. The leaching of ores containing uranium in the tetravalent state is more difficult. Oxidizing agents such as sodium perchlorate and pyrolusite are often added to convert the uranium to the hexavalent state. Acid leaching of uranium from Fernald soils may not be applicable because these soils contain appreciable quantities of carbonate minerals [ 20 to $40 \%$ by weight of calcite and dolomite minerals 5 . Thus, the soils would require excessive quantities of acid and would generate copious quantities of secondary waste. 
Screening tests were conducted to determine the effectiveness of extracting uranium from the Fernald soils using four chemical extraction processes ${ }^{6}$. These included sulfuric and citric acid extractions, a reductive dissolution process [citrate-bicarbonate-dithionite, called the CBD extraction] and extractions with carbonate. The sulfuric and citric acid extractions were conducted a pH values between 1 and 2 over extraction periods up to 18 hours. The CBD extraction is a commonly used procedure to selectively remove free iron hydrous oxides and hydroxides from soils ${ }^{7}$. It utilizes sodium dithionite for reduction purposes in a sodium carbonate buffer $(\mathrm{pH} 7.3)$ with sodium citrate for sequestering ferric and ferrous ions. Only the carbonate extractions are highly selective for uranium. Figure 1 illustrates that the carbonate extraction process removes similar levels of uranium but very little iron or calcium as compared to the CBD and the acid extractions. Thus, the CBD and acid extractants generate large volume secondary waste streams containing high levels of iron, calcium, sulfate, citrate, and uranium concentrations that are difficult to manage and dispose of. These extractions also generate wastewater streams that are difficult to treat chemically or physically.

Unlike acid and other chemical extractions, carbonate extractions are highly selective for uranium. The efficiency of the carbonate extractions is based on the formation of sodium or ammonium uranyl tri- and dicarbonates $\left[\mathrm{UO}_{2}\left(\mathrm{CO}_{3}\right)_{2}{ }^{2}\right.$ and $\left.\mathrm{UO}_{2}\left(\mathrm{CO}_{3}\right)_{3}{ }^{4}\right]$, highly stable, water-soluble anionic complexes. Oxidants such as potassium permanganate, hydrogen peroxide, perchlorates, and dissolved oxygen, as well as catalysts such as ferrocyanide or copper salts, may be used to increase the carbonate-bicarbonate extraction efficiency of uranium contained in primary minerals in the tetravalent form.

\section{RESULTS AND DISCUSSION}

\section{Role of Carbonate-Bicarbonate Concentration and pH}

Factorial-designed experiments were conducted on each of the contaminated soils. Three concentrations of total carbonate-bicarbonate $(0.10,0.25$, and $0.50 \mathrm{M})$ were used at three initial $\mathrm{pH}$ levels $-8,9$, and 10 . Figures 2 and 3 illustrate the fractions of uranium extracted after $4 \mathrm{~h}$ in a rotary type extractor at a liquid-to-solid ratio of $10: 1(200 \mathrm{~mL}$ of extractant and $20 \mathrm{~g}$ of soil).

The removal of uranium from either of the two soils was statistically independent of extraction $\mathrm{pH}$ and concentration of carbonate-bicarbonate (at the $5 \%$ level). Removal of uranium from the incinerator soil (Fig. 2) 
was more difficult than removal from the storage pad soil (Fig. 3). These experiments as well as experiments conducted in latter stages of the bench-scale studies indicated that concentrations of cabonate-bicarbonate in the range of 0.25 and $0.50 \mathrm{M}$ were equivalent and that the $\mathrm{pH}$ of the extraction, if between 8.0 and 9.5 , was not a major variable in extraction of uranium from the Fernald soils. Tests evaluating the recovery of uranium from the carbonate-bicarbonate lixiviants showed that more than $90 \%$ of the uranium could be removed from the lixiviant containing $\leq 0.25 \mathrm{M}$ total carbonate-bicarbonate ( $\mathrm{pH} 9.3$ ) in a single contact with commercially available resins. At carbonate-bicarbonate concentrations of $0.5 \mathrm{M}$, uranium removal from the lixiviant was very poor. Thus, the pilot-scale testing was conducted at $0.25 \mathrm{M}$.

\section{Influence of Time and Temperature}

Two other variables investigated were temperature and time of extraction (when a $0.5 \mathrm{M}$ carbonate-bicarbonate concentration was used). The influence of each appeared to be dependent on the particular uranium-contaminated soil being tested. For example, increased extraction time increased uranium extraction from the Fernald incinerator soil but not from the storage pad soil (Fig. 4). Similarly, increasing temperature increased removal of uranium from the incinerator soil but not from the storage pad soil (Fig. 5). The likely reason for such observations was that the composition of the storage pad soil made extraction easier under any circumstances and, therefore less dependent on the variables being investigated. The Fernald incinerator soil contained nearly equal concentrations of uranium in the sand and clay fractions whereas the clay fraction of the storage pad soil contained nearly ten times more uranium than the sand fraction (see Table 1). In addition to the simple influence of larger available surface area of uranium in the clay fraction of the storage pad soil, characterization data indicated the presence of recalcitrant low-fired uranium metaphosphate particles in the incinerator soil whereas the uranium form in the storage pad soil appear to be dominated by schoepite (uranyl oxide hydrate) in close association with amorphous iron oxyhydroxide coatings ${ }^{4}$.

\section{Role of Attrition Scrubbing}

Attrition scrubbing is a physical process intended to dislodge and remove or scarify finer size particulate from sand size particles. It is commonly used in the uranium mining and milling industry to enhance extraction efficiencies. Bench-scale studies revealed 10 to $15 \%$ better 
extraction effectiveness for uranium from the Fernald incinerator soil when a Denver Equipment attrition scrubber was used (Model 533) instead of the simple end-to-end rotary extraction technique (liquid-to-solid ratio of 10:1). Interestingly, attrition scrubbing at $55 \%$ solids was not as effective as attrition scrubbing at $33 \%$ solids. No difference was noted in the extractability of uranium from the Fernald storage pad soil.

A pilot-scale study was also conducted to evaluate the influence of attrition scrubbing. The Fernald incinerator soil was fed to the pilot-scale attrition scrubber (a two-cell unit design with a capacity of $4 \mathrm{ft}^{3}$ ). Samples were removed after $15,30,45$, and 60 min of attrition and then used in a factorial designed experiment (four replicates) to investigate the removal of uranium as a function of carbonate-bicarbonate concentration ( 0.25 and $0.50 \mathrm{M}$ ) and temperature (25 and $40 \mathrm{C}$ ). This experiment indicated little advantage in the use of attrition scrubbing. Attrition scrubbing at $15 \mathrm{~min}$ released approximately $5 \%$ more uranium (across both temperatures and carbonate-bicarbonate concentrations) than no attrition scrubbing (Fig. 6). Attrition scrubbing at 30,45 , and 60 min yielded extraction efficiencies of uranium similar to those of samples not scrubbed. More detailed analysis indicated that prolonged attrition scrubbing ( $>30 \mathrm{~min}$ ) followed with extraction at elevated temperatures actually decreased removal rates of

uranium from the Fernald incinerator soil. Follow-up attrition studies in the laboratory with soil fractions of $>20 \mathrm{~m}$ also showed little advantage in the use of an attrition scrubber.

\section{Influence of a Chemical Oxidant}

Chemical oxidants are used extensively in the industry to enhance oxidation of highly resistant uranite mineral forms (those minerals containing predominately tetravalent uranium) to the uranyl forms, which form soluble complexes with sulfuric acid and carbonate extracts.

Potassium permanganate $\left(\mathrm{KMnO}_{4}\right)$, though expensive on a commercial scale, is a good oxidant for carbonate extractants because of its high oxidation capacity in mildly alkaline solutions. Potassium permanganate amendments $\left(0.02 \mathrm{~g}\right.$ of $\mathrm{KMnO}_{4}$ per $\mathrm{g}$ of soil) increased extraction effectiveness of uranium by approximately $10 \%$ for the Fernald incinerator soil but had little influence on the ability of carbonates to extract uranium from the storage pad soil (Fig. 7).

\section{Successive Extractions}

To determine if successive extractions of carbonates would remove significantly more uranium than an initial single extraction, the Fernald 
incinerator soil was extracted five times in succession with $0.1,0.25$, and $0.5 \mathrm{M}$ carbonate-bicarbonate ( $\mathrm{pH} 9.5$, without $\mathrm{KMnO}_{4}$ amendments).

These extractions involved 16-h extraction times in a rotary extractor at a liquid-to-solid ratio of 2:1 (replicated in triplicate). At the higher carbonate-bicarbonate concentrations $(0.25$ and $0.50 M)$, approximately $90 \%$ of the extractable uranium was removed in the initial extraction. The remaining $8 \%$ and $2 \%$ were extracted in the second and third extractions. Uranium removal in the initial extraction was statistically the same for the 0.25 and $0.50 \mathrm{M}$ concentrations and approximately $10 \%$ more effective than the $0.10 \mathrm{M}$ carbonate-bicarbonate concentration.

\section{The Potential to Recycle Lixiviant}

An important aspect in determining the applicability of an extraction technology is the ability to recycle the extractant for additional extractions of uranium from soil. To test the applicability of recycling a sodium carbonate extractant, extractant from a previous carbonate extraction was used to extract uranium from soil. This process was repeated through seven recycles (Fig. 8). Fresh carbonate extract was added only to make up for entrained losses during the liquid-to-solid separation process (keeping the liquid-to-solid ratio equal to 2:1 during the extractant stage).

Extraction effectiveness was lowered to approximately 200 to $250 \mathrm{mg}$ of uranium per $\mathrm{kg}$ of soil in the sixth and seventh recycles as compared to 300 to $350 \mathrm{mg}$ of uranium per $\mathrm{kg}$ of soil in the initial two extractions. These data imply a slight decline in extraction effectiveness of uranium on continued recycle. However, uranium concentrations of 100 to $250 \mathrm{mg} / \mathrm{L}$ in the first and second recycle certainly do not significantly affect extraction efficiency and indicate that any recycled carbonate extractant containing these levels of uranium will not affect overall extraction effectiveness.

\section{Pilot-Scale Studies}

The pilot-scale study conducted at the Fernald site used carbonate extractants to remove uranium from the Fernald storage pad and incinerator soils. The facility operated in a batch-mode and treated between 350 and $400 \mathrm{lbs}$. of soil at a time. The facility contained trommel and vibrating screens, an attrition scrubber, a centrifuge, and several reaction vessels (one jacketed for temperature-related studies). Detailed operating procedures and treatments conducted are available ${ }^{8}$. 
Several parameters were investigated, the main ones being the influence of attrition scrubbing and elevated temperatures on rates of uranium removal. The basic extraction process was carried out over a 2-h extraction period and used $0.25 \mathrm{M}$ sodium carbonate-bicarbonate ( $\mathrm{pH}$ 9.5) containing $0.02 \mathrm{~g}$ of $\mathrm{KMnO} 4$ per $\mathrm{g}$ of treated soil. Uranium concentration in the extraction was measured at various extraction intervals and revealed that uranium removal was very rapid; $85 \%$ of what was extracted in $2 \mathrm{~h}$ was removed in the first $15 \mathrm{~min}$. Heating to $40 \mathrm{C}$ removed greater levels of uranium from the incinerator soil, and equilibrium levels of uranium in the reactor were attained more quickly, indicating that heating to $40 \mathrm{C}$ should be a practical application in a commercial-scale operation.

The process removed approximately $90 \pm 5 \%$ of the uranium from the storage pad soil and $80 \pm 5 \%$ of the uranium from the incinerator soil. Starting concentrations of uranium in the storage pad soil ranged from approximately 1700 to $2000 \mathrm{mg} / \mathrm{kg}$. Uranium concentrations in the treated storage pad soils were usually $<150 \mathrm{mg} / \mathrm{kg}$. Initial uranium concentrations in the untreated incinerator soil were not as high (ranging from approximately 500 to $1000 \mathrm{mg} / \mathrm{kg}$ ), but treated concentrations were always $<200 \mathrm{mg} / \mathrm{kg}$. The best treatment was three successive extractions at $40 \mathrm{C}$ with $0.25 \mathrm{M}$ carbonate-bicarbonate followed with two water rinses. For the Fernald incinerator soil, this treatment produced a final product containing approximately $85 \mathrm{mg} / \mathrm{kg}$ uranium.

\section{CONCLUSIONS}

Experimental data obtained at the bench- and pilot-scale levels indicated 80 to $95 \%$ of the uranium could be removed from the Fernald soils by using a carbonate lixiviant. Uranium concentrations in the Femald storage pad soil ranging from 1700 to $2000 \mathrm{mg} / \mathrm{kg}$ could be lowered to concentrations in the range of 100 to $150 \mathrm{mg} / \mathrm{kg}$. Uranium in the Fernald incinerator soil was more difficult to extract; however, initial uranium concentrations were lower, ranging from 500 to $1000 \mathrm{mg} / \mathrm{kg}$. Final concentrations in the carbonate-bicarbonate-treated Fernald incinerator soil ranged from 85 to $150 \mathrm{mg} / \mathrm{kg}$. The best treatment was three successive extractions with $0.25 \mathrm{M}$ carbonate-bicarbonate (in presence of $\mathrm{KMnO}_{4}$ as an oxidant) at $40 \mathrm{C}$ followed with two water rinses.

The influence of various factors on carbonate extraction of uranium from the Fernald soils can be summarized as follows: (1) initial extraction is rapid ( $<30 \mathrm{~min}$ ) for $90 \%$ of extractable uranium, (2) increased extraction occurs when temperature is increased from $25 \mathrm{C}$ to $40 \mathrm{C}$, but little effect is shown at $>40 \mathrm{C}$., (3) equal extraction efficiency at concentrations of 0.25 and $0.50 \mathrm{M}$ (especially at 40 to $45 \mathrm{C}$ ) appear to be equivalent, and both 
concentrations have greater extraction efficiency than the $0.10 \mathrm{M}$ concentration, (4) effect of pH does not vary between 8 and 10, (5) attrition scrubbing shows little effect, (5) data indicate a possible $>10 \%$ but $<20 \%$ increase in extraction efficiency when an oxidant is used (only for the incinerator soil), (6) approximately 85 to $90 \%$ of extractable uranium is removed in the initial extraction, and the remaining uranium is removed in the second and third extractions, (7) carbonate extractant can be easily recycled two and maybe three times with little effect on extraction efficiency of uranium.

\section{ACKNOWLEDGMENTS}

This work was supported by the U.S. Department of Energy, Office of Technology Development and conducted by Oak Ridge National Laboratory, Oak Ridge, Tennessee, managed by Lockheed Martin Energy Systems, Inc. under contract DE-AC05-84OR21400. Appreciation is expressed to Kim Nuhfer, Program Coordinator for the Uranium in Soils Integrated Demonstration Program, for administrative support throughout the project.

\section{REFERENCES}

(1) Soil Decon Task Group, Uranium in Soils Integrated Demonstration. Removal of Uranium from Uranium-Contaminated Soils, Phase I: Bench-Scale Testing, ORNL-6762, Oak Ridge National Laboratory, Oak Ridge, Tenn., 1993.

(2) P.G. Allen, J.M. Berg, C.J. Crisholom-Brause, S.D. Conradson, R.J. Donohoe, D.E. Morris, Determining Uranium Speciation in Fernald Soils by Molecular Spectroscopic Methods, LA-12799-PR, Los Alamos National Laboratory, Los Alamos, NM., 1994.

(3) P.M. Bertsch, D.B. Hunter, S.R. Sutton, S. Bajt, M.L. Rivers, Environ. Sci. Technol. 28 (1994), 980.

(4) E.C. Buck, J.C. Cunnane, N.L. Dietz, N.R. Brown, Analytical Electron Microscopy Characterization of Uranium-Contaminated Soils from the Fernald Site, FY 1993 Report, ANL-94/38, Argonne National Laboratory, Argonne, III., 1994.

(5) M.P. Elless, S.Y. Lee, Physicochemical and Mineral Characterization of Transuranic Contaminated Soils for Uranium Soil Integrated Demonstration, ORNL/TM-12848, Oak Ridge National Laboratory, Oak Ridge, Tenn., 1993. 
(6) C.W. Francis, A.J. Mattus, L.L. For, M.P. Elless, S. Y. Lee, Selective Leaching of Uranium from Uranium-Contaminated Soils: Progress Report 1, ORNL/TM-12177, Oak Ridge National Laboratory, Oak Ridge, Tenn., 1993.

(7) M.L. Jackson, C.H. Kim, L.W. Zelazmy, pp 101-150, In Methods of Soil Analysis, Part 1 -Physical and Mineralogical Methods, ind Ed.; Number 9 (Part 1) in the series Agronomy, American Society of Agronomy, Inc., Soil Science Society of America, Inc., Madison, Wisc. 1986.

(8) J.H. Wilson, R. Chernikoff, W.D. DeMarco, C.W. Francis, L.L. Stebbins, Carbonate and Citric Acid Leaching of Uranium from Uranium-Contaminated Soils: Pilot-Scale Studies, ORNLTM-12560, Oak Ridge National Laboratory, Oak Ridge, Tenn., 1995.

$1 n$ 
Table 1. Concentration and distribution of uranium in the Fernald soils

\begin{tabular}{|c|c|c|c|c|}
\hline Soil & $\begin{array}{l}\text { Size fraction } \\
(\mathrm{mm})\end{array}$ & $\begin{array}{l}\text { Particle size } \\
\text { distribution } \\
\text { (\%) }\end{array}$ & $\begin{array}{c}\text { Uranium } \\
\text { concentration } \\
(\mathrm{mg} / \mathrm{kg})\end{array}$ & $\begin{array}{l}\text { Uranium } \\
\text { burden } \\
\text { by size } \\
\text { fraction } \\
(\%)\end{array}$ \\
\hline \multirow[t]{3}{*}{ Incinerator } & $\begin{array}{c}\text { Total soil } \\
\text { Sand } \\
(2.0-0.053)\end{array}$ & $\begin{array}{l}\mathrm{na}^{1} \\
12.5\end{array}$ & $\begin{array}{c}538 \\
1033\end{array}$ & $\begin{array}{l}\text { na } \\
27\end{array}$ \\
\hline & $\begin{array}{c}\text { Silt } \\
(0.053-0.002)\end{array}$ & 73.9 & 286 & 44 \\
\hline & $\begin{array}{c}\text { Clay } \\
(<0.002)\end{array}$ & 13.6 & 1019 & 29 \\
\hline \multirow[t]{3}{*}{$\begin{array}{l}\text { Storage } \\
\text { Pad }\end{array}$} & $\begin{array}{c}\text { Total soil } \\
\text { Sand } \\
(2.0-0.053)\end{array}$ & $\begin{array}{c}\text { na } \\
22.6\end{array}$ & $\begin{array}{l}446 \\
117\end{array}$ & $\begin{array}{c}\text { na } \\
7\end{array}$ \\
\hline & $\begin{array}{c}\text { Silt } \\
(0.053-0.002)\end{array}$ & 56.5 & 239 & 37 \\
\hline & $\begin{array}{c}\text { Clay } \\
(<0.002)\end{array}$ & 20.9 & 983 & 56 \\
\hline
\end{tabular}

${ }^{1}$ na $=$ not applicable 


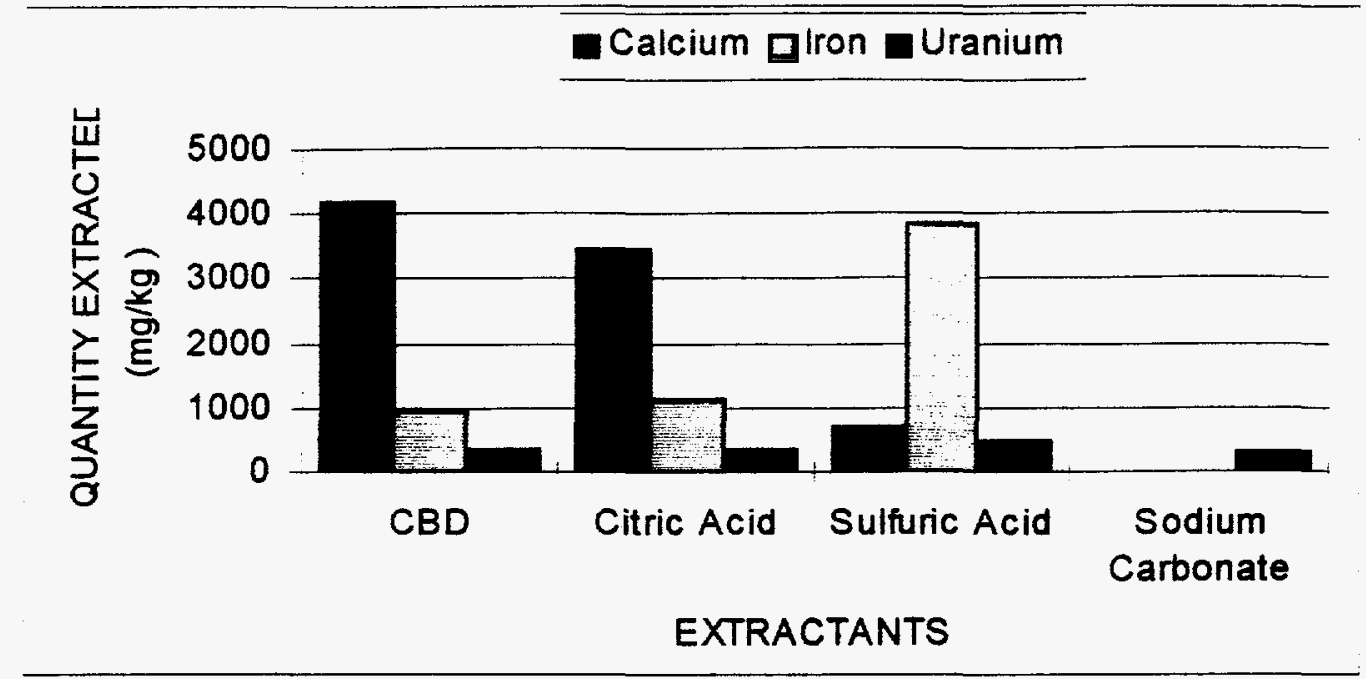

Figure 1. Quantities of calcium, iron, and uranium removed from the Fernald incinerator soil by the four extractants (CBD is a reductive dissolution process using a sodium citrate, bicarbonate, and dithionate extractant). 


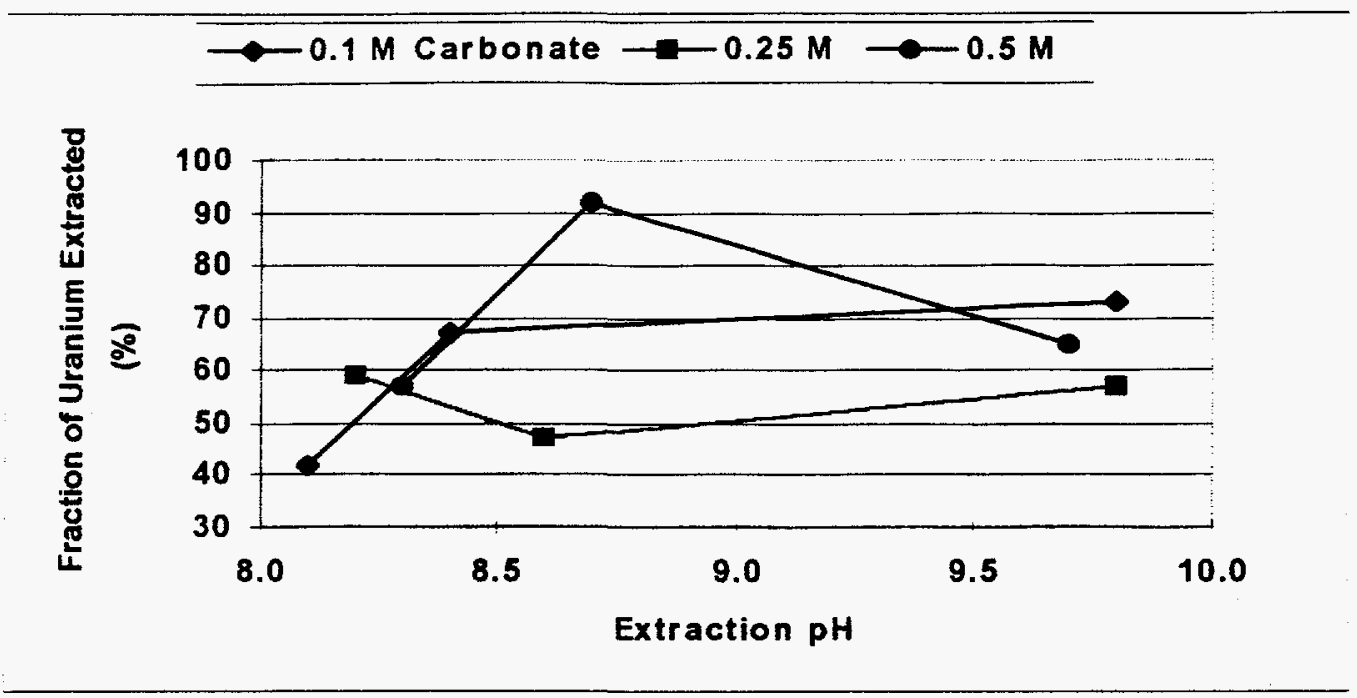

Figure 2. Fraction of uranium extracted from the Fernald incinerator soil as a function of final extraction $\mathrm{pH}$ and carbonate/bicarbonate concentration $(0.10,0.25$, and $0.50 \mathrm{M})$. 


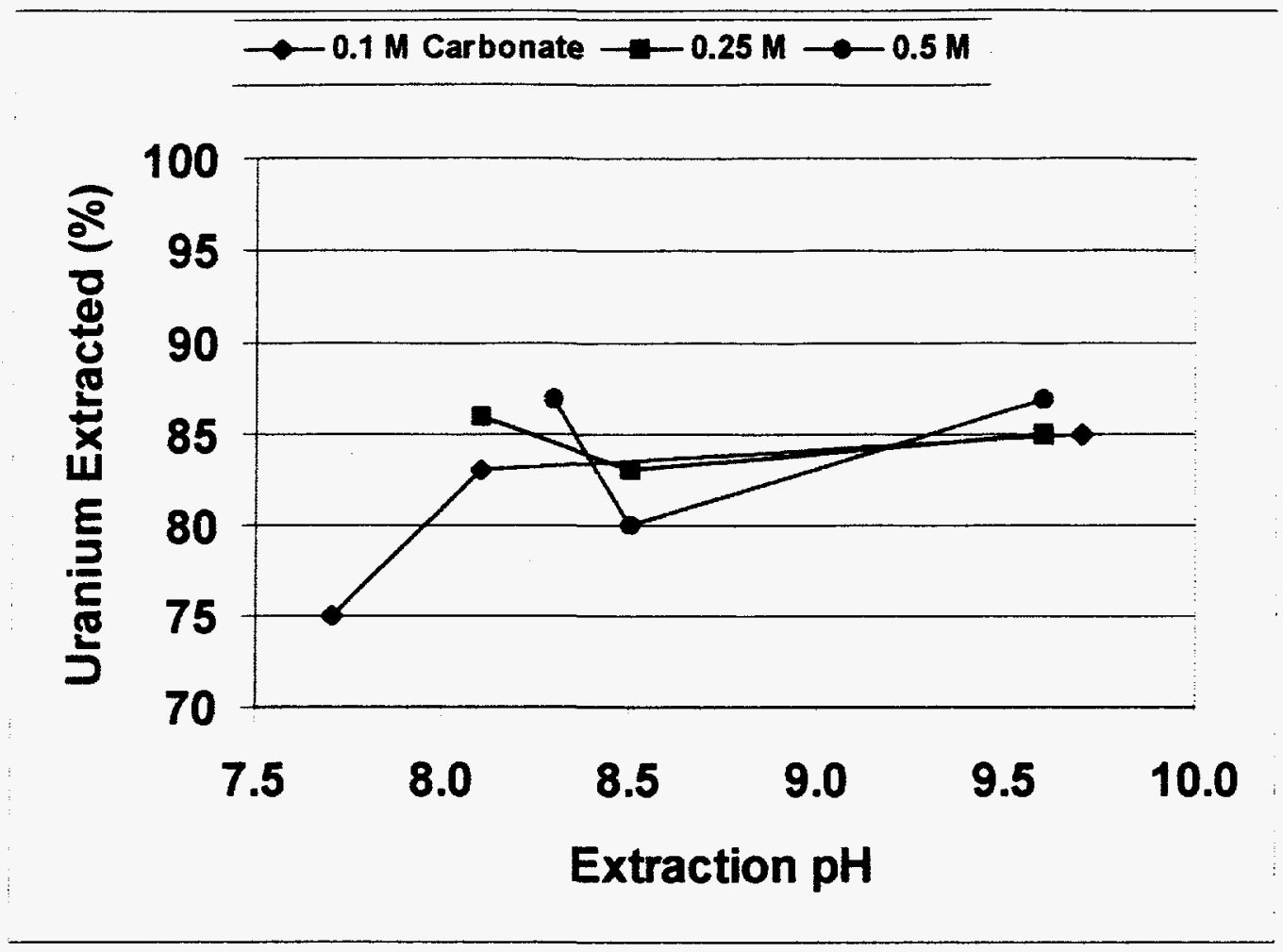

Figure 3. Fraction of uranium extracted from the Fernald storage pad soil as a function of final extraction $\mathrm{pH}$ and carbonate/bicarbonate concentration $(0.10,0.25$, and $0.50 \mathrm{M})$. 


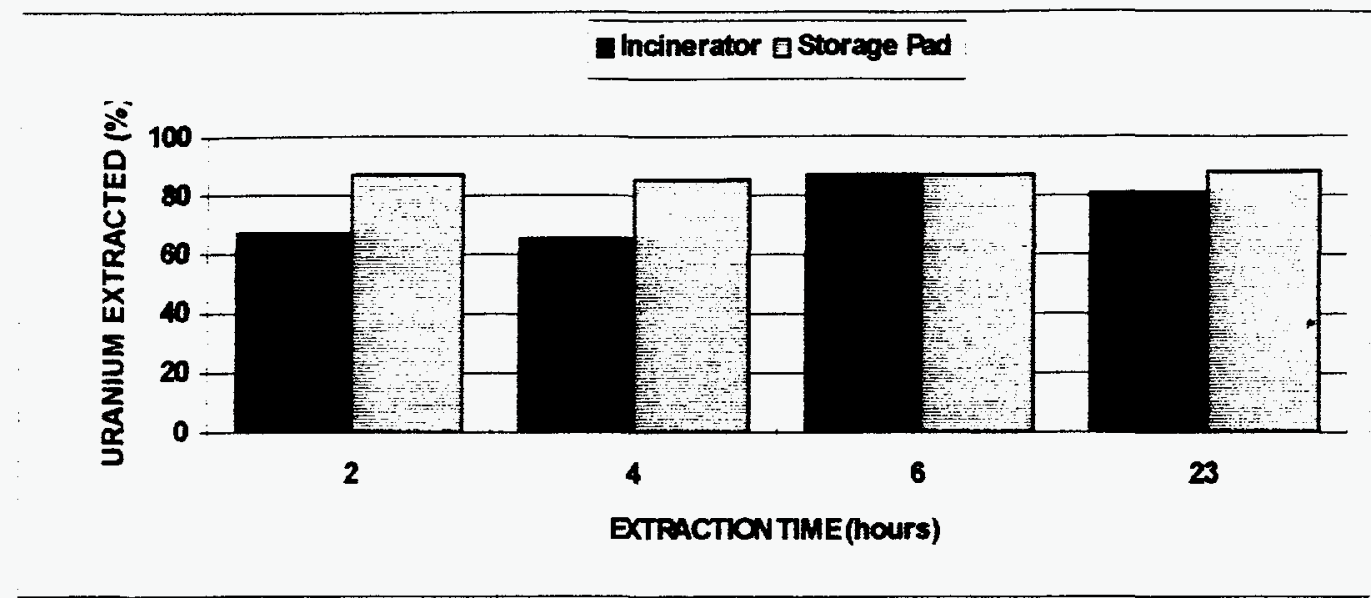

Figure 4. The influence of time on the removal of uranium from the Fernald soils by a $0.50 \mathrm{M}$ carbonate-bicarbonate extractant. 


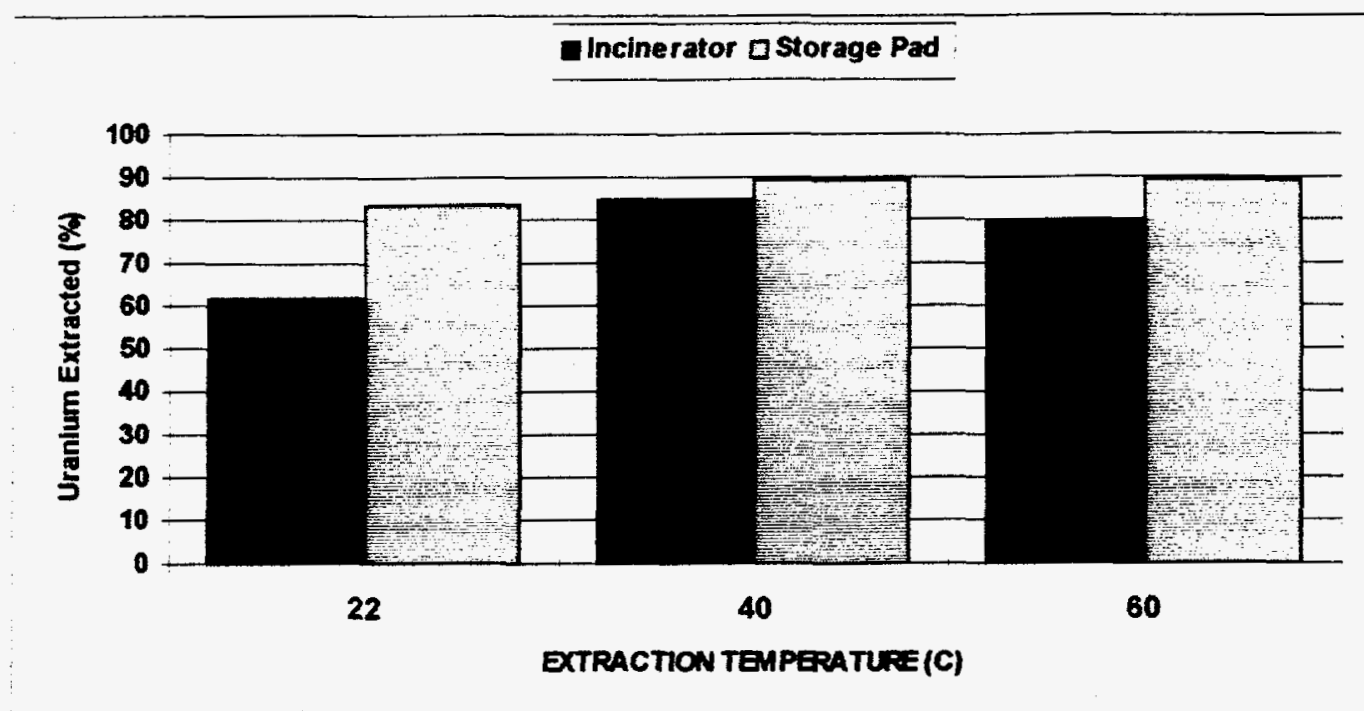

Figure 5. The influence of temperature on the removal of uranium from the Fernald soils by $0.50 \mathrm{M}$ carbonate-bicarbonate extractant. 


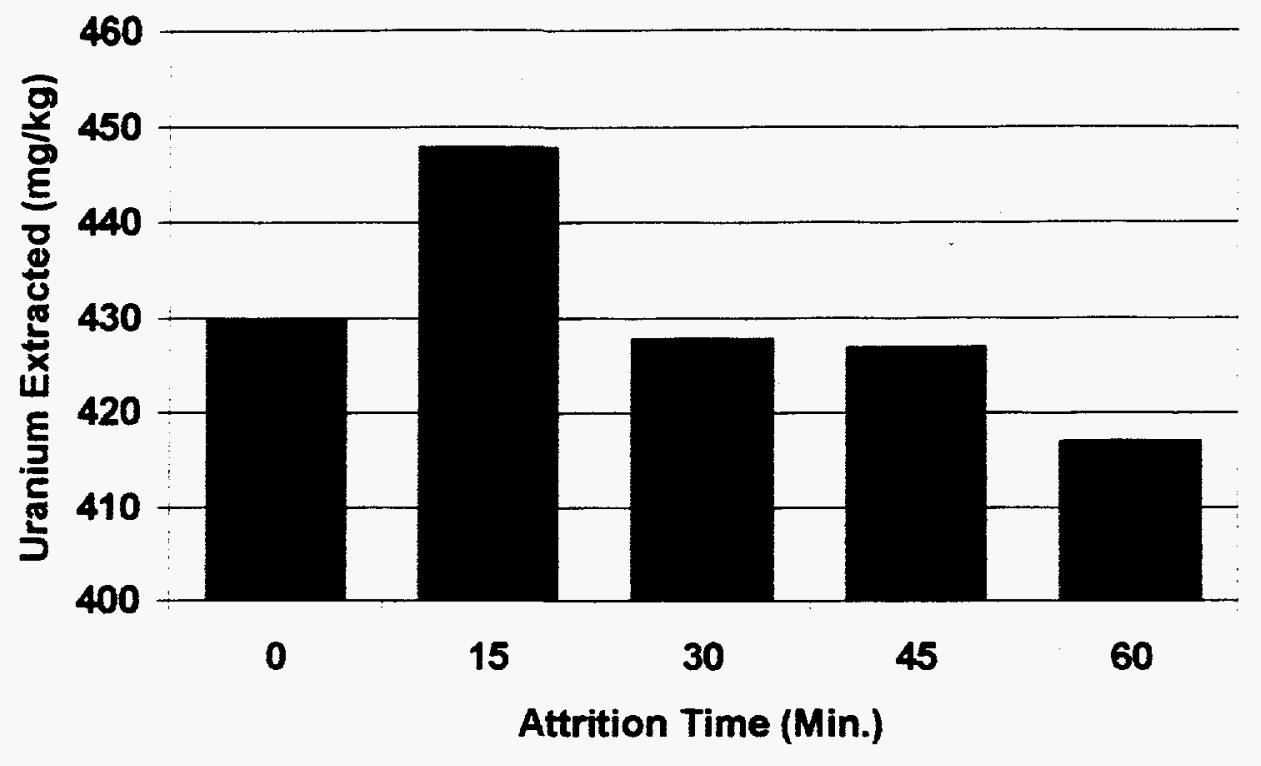

Figure 6. The influence of attrition scrubbing on the removal of uranium from the Fernald incinerator soil (main effects across 0.25 and $0.50 \mathrm{M}$ carbonate-bicarbonate concentrations and 25 and $40^{\circ} \mathrm{C}$ extraction temperatures). 


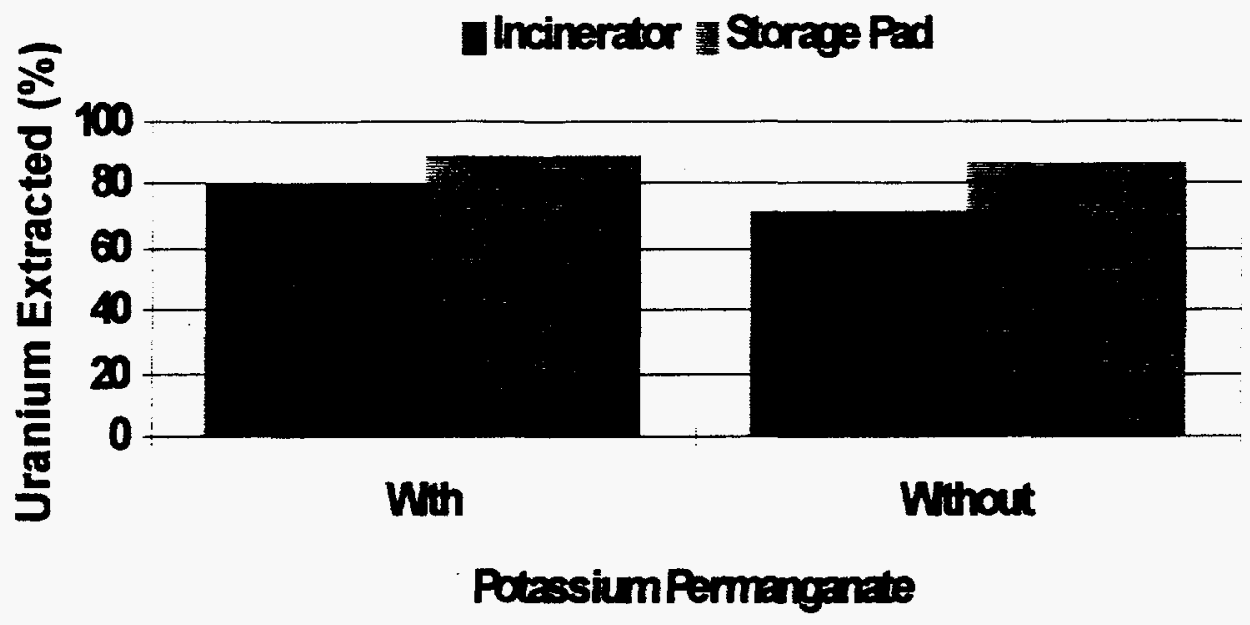

Figure 7. The influence of adding potassium permanganate to carbonate-bicarbonate extractions for uranium removal. 


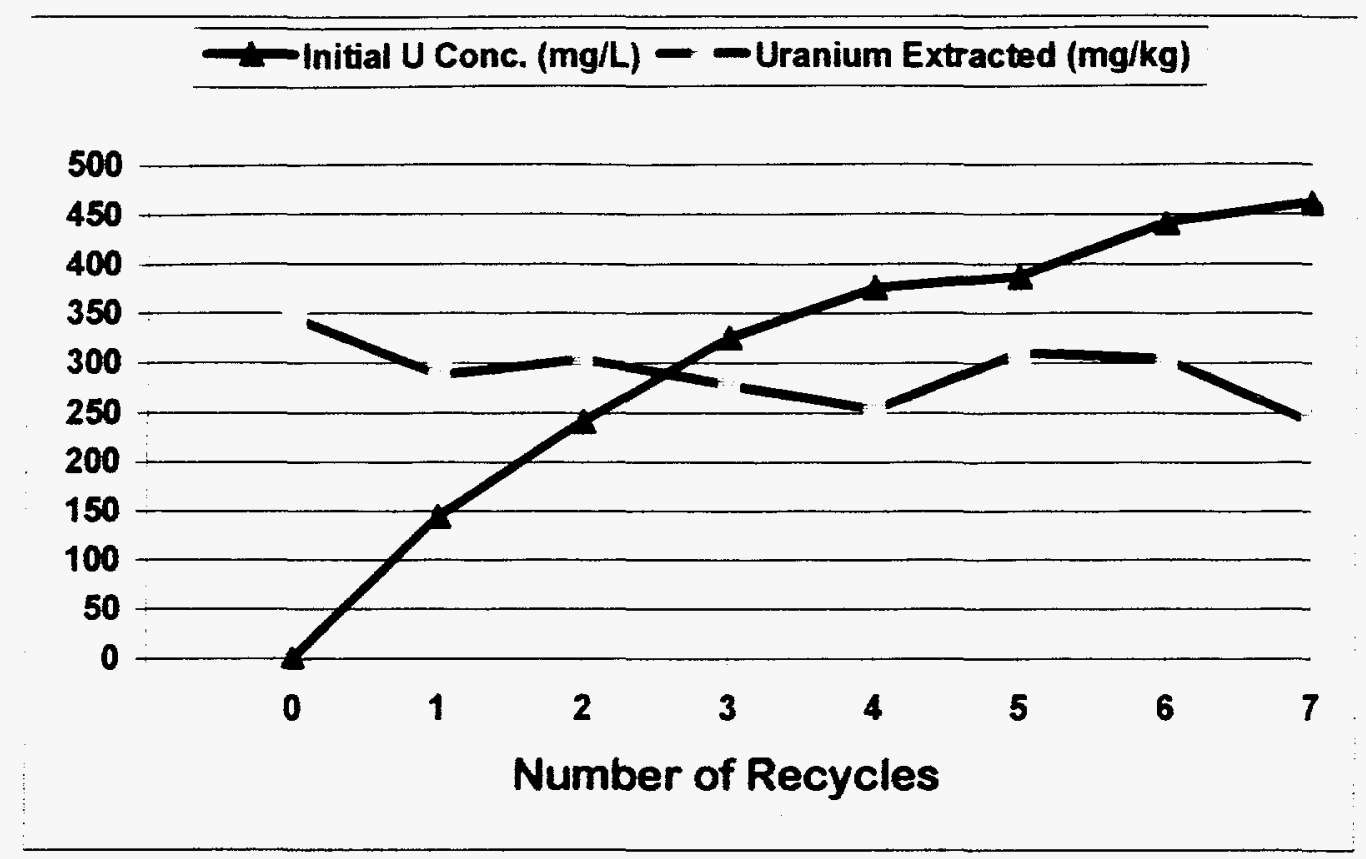

Figure 8. The effect of recycling carbonate-bicarbonate extractant $(0.50 \mathrm{M}$, $40^{\circ} \mathrm{C}, 15 \mathrm{~h}$ ) on extraction of uranium from the Fernald incinerator soil.

\section{DISCLAIMER}

This report was prepared as an account of work sponsored by an agency of the United States Government. Neither the United States Government nor any agency thereof, nor any of their employees, makes any warranty, express or implied, or assumes any legal liability or responsibility for the accuracy, completeness, or usefulness of any information, apparatus, product, or process disclosed, or represents that its use would not infringe privately owned rights. Reference herein to any specific commercial product, process, or service by trade name, trademark, manufacturer, or otherwise does not necessarily constitute or imply its endorsement, recommendation, or favoring by the United States Government or any agency thereof. The views and opinions of authors expressed herein do not necessarily state or reflect those of the United States Government or any agency thereof. 


\section{DISCLAMIER}

Portions of this document may be illegible in electronic image products. Images are produced from the best available original document. 